\title{
Penerapan Upaya Pencegahan dan Penanganan Aspirasi Benda Asing dan Kejang Demam pada Anak di Rumah
}

\author{
Sri Melfa Damanik ${ }^{1}$, Erita Sitorus ${ }^{2}$, I Made Mertajaya ${ }^{3}$ \\ 1,2,3 Universitas Kristen Indonesia, Jakarta, Indonesia \\ melfadamanik20@gmail.com; eritasitorus1@gmail.com; immerta@yahoo.com
}

\begin{abstract}
Abstrak
Masalah kegawatan aspirasi benda asing atau tersedak dan kejang demam pada anak usia Toddler merupakan salah satu kondisi kegawatan yang serius pada anak dan mengancam nyawa bila tidak ditangani segera. Observasi oleh pengasuh khususnya orangtua sangat penting dilakukan pada periode usia anak pada periode ini. Penanganan aspirasi benda asing dan kejang demam pada anak pre hospital dengan cepat dan tepat dapat mencegah peningkatan insiden morbiditas dan mortalitas anak. Tujuan Pelaksanaan Pengabdian kepada Masyarakat (PKM) ini yaitu untuk meningkatkan pengetahuan dan ketrampilan orangtua ibu tentang pencegahan dan penanganan aspirasi benda asing dan kejang demam pada anak Toddler di rumah. Sebanyak 30 ibu yang memiliki anak Toddler ikut dalam kegiatan PKM ini. Metode pelaksanaan PKM yaitu edukasi kesehatan secara daring melalui Zoom yang dikombinasikan dengan survei secara kuantitatif tentang pengetahuan ibu dalam melakukan pencegahan dan penanganan aspirasi benda asing dan kejang demam pada anak. Hasil PKM menunjukkan terdapat perbedaan yang signifikan antara nilai pre dan posttest pengetahuan ibu setelah diberikan sosialisasi. Kegiatan edukasi kesehatan kepada orangtua khusunya ibu atau pengasuh tentang pencegahan dan penanganan aspirasi benda dan kejang demam di rumah merupakan salah satu cara yang efektif untuk mengurangi angka morbiditas dan mortalitas pada anak di Indonesia.
\end{abstract}

Kata Kunci : Toddler, kejang demam, aspirasi benda asing. Peran lbu

\begin{abstract}
The emergency problem of foreign body aspiration or choking and febrile seizure in Toddlers is a serious emergency condition in children if not treated immediately can be life threatening for child. Observation by caregiver especially parents are very importants way during the child'age period. Handling foreign body aspiration and febril seizures in pre hospital quickly and immediately can prevent number of incident morbidity and mortality for Toddlers. The purpose of this Study is to increase the knowledge and skills of parents about preventing and handling foreign body aspiration and febrile seizures in Toddlers at home. There are thirty mothers who have toddler children participated in this study. The method of this study is online health education via Zoom combinated with a quantitative survey. The results showed that there was asignificant difference between pre and post test values of mother knowledge after being given socialization $(P<0,001)$. Health education activities to parents especially mother or care givers about preventing and handling foreign body aspiration and febrile seizures at home are one effective way to reduce morbidity and mortality of incident injury children in Indonesia.
\end{abstract}

Keywords: Toddlers, Febrile seizure, chocking, role of mother 
Volume 3, Nomor 2, Tahun 2021 Hal 653 - 661

\section{PENDAHULUAN}

Cidera pada masa anak-anak berpotensi menimbulkan dampak merugikan yang spesifik pada kesehatan dan perkembangan anak (Crandall, Sridharan, \& Schermer, 2011). Permasalahannya, anak yang aktif tidak pernah lepas dari keadaan gawat selama diasuh oleh orangtua di rumah. Anak secara unik rentan terhadap berbagai situasi kedaruratan, situasi ini sering kali mengancam jiwa jika tidak ditangani secara cepat dan efektif. Sebagian besar henti jantung paru pada pediatrik terjadi akibat gagal nafas atau syok (Kyle \& Carman, 2013).

Gawat darurat adalah keadaan klinis pasien yang membutuhkan tindakan medis segera untuk menyelamatkan nyawa dan pencegahan kecacatan (Permenkes RI No. 19 Tahun 2016 tentang Sistem Penanggulangan Gawat Darurat Terpadu). Keadaan kegawatdaruratan pada anak yang terjadi di rumah sering kali membuat orangtua atau pengasuh panik, bingung, dan tidak tahu harus berbuat apa. Permasalahan kegawatan pada anak di rumah bukan hanya problem orangtua atau pasangan muda yang baru memiliki anak saja, tetapi merupakan permasalahan orangtua secara umum.

Ada banyak kasus kegawatan pada anak yang ditemukan di masyarakat. Di Amerika pada tahun 2006 usia 18 tahun kebawah melakukan lebih dari 237 juta kunjungan ke pelayanan kesehatan. 24 juta kunjungan diantaranya berobat jalan dan ke departemen emergensi. Mayoritas kunjungan adalah untuk kasus akut dan 54\% kunjungan anak usia 5-14 tahun karena cidera (Trokel et. al., 2006). Di Indonesia prevalensi cedera nasional adalah $8,2 \%$. Prevalensi cedera tertinggi berdasarkan kharakteristik responden kelompok umur 15-24 tahun (11,7\%), pendidikan tamat SMP $(9,1 \%)$ dan bertempat tinggal diperkotaan (8,7\%). Ditinjau dari penyebab cederanya proporsi tertinggi adalah karena jatuh $(91,3 \%)$ pada kelompok umur $<1$ tahun (Riskesdas, 2013)

Beberapa kondisi kegawatan pada anak yang sering ditemukan adalah aspirasi benda asing, jatuh atau kecelakaan serta kejang. Benda asing merupakan masalah serius yang terjadi pada anak-anak dengan angka morbiditas dan mortalitas yang tinggi. Benda asing harus dikeluarkan sesegera mungkin agar tidak menimalkan komplikasi yang dapat mengancam nyawa. Sekitar 75-85\% kasus aspirasi benda asing terdapat pada anak-anak dibawah umur 15 tahun dimana penderita terbanyak adalah anak usia kurang dari 3 tahun ( WHO, 2016). Hal ini tentunya dapat diatasi bila orang tua memiliki pengetahuan yang baik tentang penanganan dini saat kondisi tersebut terjadi di rumah atau lingkungan masyarakat.

Kejang demam pada anak juga merupakan salah satu jenis cidera yang sering dialami 
Volume 3, Nomor 2, Tahun 2021 Hal 653 - 661

oleh anak Toddler. Kejang demam pada anak murni diakibatkan dari respon tubuh karena adanya demam yang diakibatkan oleh infeksi selai infeksi pada system saraf pusat. Peran pengasuh khususnya orang tua sangat penting dalam mencegah dan menangani anak kejang demam di rumah sebelum dibawa ke rumah sakit bila kondisi semakin memburuk.

Pemberian edukasi kesehatan kepada ibu tentang penanganan kejang demam dan aspirasi benda asing pada anak balita khususnya anak usia Toddler merupakan hal yang sangat penting dilakukan agar orangtua dapat melakukan pertolongan pertama pada anak dan mengurangi angka kesakitan bahkan kematian pada anak.

Prodi DIII Keperawatan Fakultas Vokasi UKI melakukan kegiatan pengabdian kepada masyarakat di Kelurahan Cawang dengan melakukan kegiatan penyuluhan tentang upaya pencegahan dan penanganan Aspirasi Benda Asing dan Kejang Demam pada Anak di Rumah. Sasaran dalam kegiatan ini adalah lbu-lbu yang memiliki anak Balita. Melalui kegiatan Pengabdian kepada masyarakat ini diharapkan lbu yang memiliki anak Balita memahami bagaimana upaya penatalaksanaan anak yang mengalami kejang demam dan tersedak saat di rumah.

\section{METODE}

Kegiatan pengabdian kepada masyarakat ini dilakukan dengan metode ceramah, diskusi dan tanya jawab. Sasaran kegiatan ini adalah lbu yang memiliki anak Balita. Peserta yang terlibat dalam kegiatan penyuluhan ada sebanyak 30 ibu. Semua peserta yang hadir berasal dari perwakilan masing-masing RT yang ada di Kelurahan Cawang, Jakarta Timur yang memiliki anak usia Balita. Kegiatan pengabdian ini dilakukan bekerja sama dengan Puskesmas Kelurahan Cawang pada tanggal 26 Agustus 2020 secara daring melalui Zoom. Media yang digunakan adalah media power point dan Vidio. Adapun metode sosialisasi yang digunakan adalah active and participatory learning. Dalam pelaksanaan pengabdian sebelum dan setelah penyampaian materi dilakukan pengisian kuesioner tentang karakteristik peserta, serta pengetahuan tentang penanganan kejang demam dan aspirasi benda asing atau tersedak pada anak.

Materi dalam kegiatan pengabdian kepada masyarakat ini sesuai dengan kebutuhan dan masalah yang dialami oleh lbu yang memiliki anak usia Toddler. Materi penyuluhan yang disampaikan meliputi : Pengertian, penyebab, tanda dan gejala, pencegahan dan penanganan tersedak pada anak, pertolongan pertama pada bayi dan anak bila tersedak, kapan anak dibawa ke Fasilitas Kesehatan bila anak tersedak, serta pengertian, penyebab, tanda gejala dan penatalaksanaan kejang demam pada anak Toddler. 


\section{HASIL DAN PEMBAHASAN}

Kegiatan pengabdian kepada masyarakat ini telah dipublikasikan di media online : https://bisnis.tempo.co/read/1381690/keja ng-demam-dan-tersedak-pada-anaksangat-berbahaya-ini-tips-

\section{Karakteristik responden}

Kategori responden dikategorikan

berdasarkan usia, pendidikan dan pekerjaan.

Tabel 1. Karakteristik Peserta PkM di Kelurahan Cawang, Jakarta Timur

\begin{tabular}{ccc}
\hline Kharakteristik & Jumlah Responden ( Orang) & $\%$ \\
\hline Usia & 30 & 100 \\
Dewasa ( 17-45) & & \\
Pekerjaan & 27 & 90 \\
Ibu Rumah Tangga & 3 & 10 \\
Karyawan & & \\
Pendidikan & 6 & 20 \\
SMP & 22 & 73.33 \\
SMA & 1 & 3.33 \\
D III & 1 & 3.33 \\
Sarjana & & \\
\hline
\end{tabular}

Berdasarkan data Tabel 1 menunjukkan bahwa sosialisasi tersebut diikuti oleh ibu yang memiliki anak Balita dengan semua peserta berada pada kategori usia dewasa (17-45 tahun). Ditinjau dari segi pekerjaan, sebagian besar peserta adalah ibu rumah tangga yaitu sebesar $90 \%$. Berdasarkan latar belakang pendidikan, pserta yang hadir sebagian besar dengan pendidikan terakhir SMA (73.33\%), SMP (20\%), Sarjana $(3,33 \%)$, dan Diploma (3,33 \%). Tingkat pendidikan akan mempengaruhi penanganannya-dariakademisi-uki dan http://reporter.uki.ac.id/edukasi-

kesehatan-virtual-oleh-prodi-d-iii-

keperawatan-fakultas-vokasi-ukipenanganan-aspirasi-benda-asing-dankejang-demam-pada-anak-di-rumah/

Persentase karakteristik responden disajikan dalam tabel 1. 
Volume 3, Nomor 2, Tahun $2021 \mathrm{Hal} 653$ - 661

Observasi Tingkat Pengetahuan

Kegiatan pretest dilakukan sebelum pemberian materi edukasi secara online via zoom kepada para ibu yang memiliki anak Balita di Kelurahan Cawang, Jakarta Timur. Tujuan dilakukan pretest adalah untuk mengetahui tingkat pengetahuan peserta yang hadir tentang penanganan aspirasi benda asing dan kejang demam pada anak. Terdapat 10 butir pertanyaan pretest yang berupa soal pilihan ganfa (multiple choice).

Kegiatan posttest dilakukan setelah pemberian materi oleh narasumber. Tujuan posttest dilakukan adalah untuk mengetahui adanya perubahan tingkat pengetahuan peserta setelah materi disampaikan. Sebelum post-test dilakukan terdapat sesi diskusi dimana setiap peserta memiliki kesempatan yang sama untuk bertanya kepada narasumber pada kegiatan edukasi tersebut. Adapun soal posttest sebanyak 10 butir pertanyaan yang berupa soal pilihan ganda dan jenis soalnya sama dengan soal pretest di awal. Adanya peningkatan nilai pretest-posttest setelah pemberian materi dapat dilihat pada tabel 2.

Tabel 2. Hasil uji beda nilai Pretest dan postetst peserta sosialisasi

\begin{tabular}{ccc}
\hline Jenis Evaluasi & Jumlah & Sig. $(p)$ \\
\hline Peningkatan Nilai Pretest-Post test & 27 & $\mathrm{P}<0,05$ \\
tetap & 3 & \\
\hline
\end{tabular}

Tabel 2 menunjukkan bahwa adanya peningkatan nilai pretest-posttest sebanyak 27 orang peserta sosialisasi yang hadir yaitu ibu yang memiliki anak Balita di Kelurahan Cawang, Jakarta Timur. 3 orang peserta memiliki nilai pretest dan post test tetap. Hasil uji beda antara nilai pre dan posttest menunjukkan bahwa nilai signifikansi $p<0,05$. Hasil ini menunjukkan bahwa terdapat perbedaan yang signifikan antara nilai pre dan posttest peserta sosialisasi setelah diberikan sosialisasi tentang penanganan aspirasi benda asing dan kejang demam pada anak di kelurahan cawang, Jakarta timur. Tabel 2 juga menunjukkan bahwa ada sebanyak
3 peserta yang memiliki nilai pretets dan postest yang tetap. Salah satu penyebab tidak adanya perbedaan nilai pretest dan post test dipengaruhi oleh persepsi individu. Jika persepsi antara peserta dan pemberi edukasi berbeda maka informasi yang disampaikan tidak akan maksimal.

\subsection{Edukasi kesehatan Pencegahan} dan Penanganan Kejadian aspirasi benda asing atau Tersedak dan kejang demam pada anak

Kegiatan edukasi kesehatan tentang penanganan aspirasi benda asing atau tersedak dan kejang demam di kelurahan cawang Jakarta Timur menunjukkan 
Volume 3, Nomor 2, Tahun 2021 Hal 653 - 661

bahwa adanya peningkatan pengetahuan peserta sosialisasi berdasarkan hasil survei yang dilakukan. Sebelum dilakukan sosialisasi masih banyak masyarakat yang tidak memahami langkah-langkah penanganan bila anak mengalami tersedak dan juga tatalaksana kejang demam pada anak. Namun diperoleh data bahwa setelah sosialisasi diberikan peserta sosialisasi sudah mengetahui tentang pengertian kejang demam, pencegahan dan penanganan kejang demam pada anak. Pada saat diskusi peserta juga antusias bertanya tentang pengalaman yang dirasakan oleh ibu yang pernah mengalami anak yang kejang karena demam lebih dari 38 derajat celsius.

Banyak ibu yang belum memahami penanganan kejang demam sesuai literatur yang berkembang. Menurut Ikatan dokter Indonesia penaganan kejang demam pada anak yaitu : Baringkan anak di tempat aman dan jauhkan dari benda berbahaya atau benda tajam, jangan memakai cara kekerasan untuk menahan gerakan penderita, gunakan bantal atau alas lain untuk menyangga kepala penderita, jangan memasukkan benda apapun ke dalam mulut penderita selama kejang, longgarkan pakaian yang ketat, terutama di sekitar leher penderita, miringkan kepala penderita. Bila penderita muntah, posisi miring akan mencegah muntahan masuk ke dalam paru-paru, segera panggil bantuan medis atau bantuan dari orang lain di sekitar, temani penderita sampai kejangnya berhenti atau sampai petugas medis datang.Setelah kejang berhenti, baringkan penderita pada posisi miring. Kemudian, periksa gerakan napas serta denyut nadi penderita. Berikan RJP, jika dibutuhkan (Canadian Paediatric Society, 2012).

Berdasarkan data juga ditemukan bahwa masih banyak ibu yang belum mengetahui penanganan tersedak atau aspirasi benda asing pada anak. Menurut Ikatan dokter Indonesia penagananaspirasi benda asing antara lain : Jari di satusisirahangdan yang lain menggunakan satu/dua jari tangan yang sama tanpa menekan jaringan lunak di bawah rahang, berikan 5 pukulan dengan menggunakan tumit dari telapak tangan pada bagian belakang bayi. Tindakan ini disebut Teknik Pertolongan dengan Back Blow, bila back blow gagal, balikkan bayi menjadi terlentang dan berikan 5 pijatan atau hentakan dada dengan menggunakan 2 jari (chest thrust). Jika benda asing belum keluar, ulangi lagi tindakan tersebut dari awal. Bilaanak tidak sadar lakukan resusitasi jantung paru dengan 30 kompresi dan 2 nafas bantuan. Lalu segera panggil layanan gawat darurat (Canadian Paediatric Society, 2012).

Sedangkan pada anak usia lebih dari 1 tahun, bila masih mampu mengeluarkan suara, mintaanak batuk dengan keras. Penolong jugadapat menggunakan teknik back blow dan chest thrust. Jika tidak berhasil, gunakan cara abdominal thrust. 
Volume 3, Nomor 2, Tahun 2021 Hal 653 - 661

Penolong berdiri di belakang anak.

Tangan penolong dikepalkan dan

diletakkan di antara pusar dan tulang dada anak. Raih kepalan tangan dengan tangan lainnya dan hentakan kearah atas dan belakang tubuh anak sebanyak lima kali, Bila anak mengalami sumbatan jalan nafas dan tidak sadar, lakukan bantuan hidup dasar dengan 30 kompresi dan 2 nafas bantuan sebanyak 5 siklus (Canadian Paediatric Society, 2012).

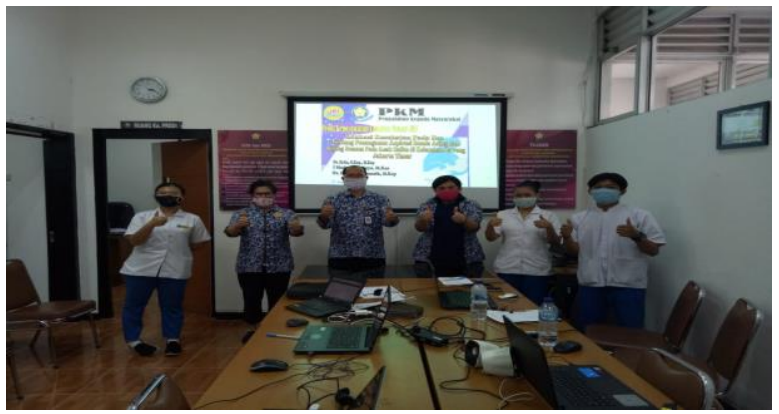

Gambar 1. Dosen dan Mahasiswa Prodi DIII Keperawatan Fakultas Vokasi UKI melakukan Kegiatan Pengabdian kepada masyarakat Cawang.

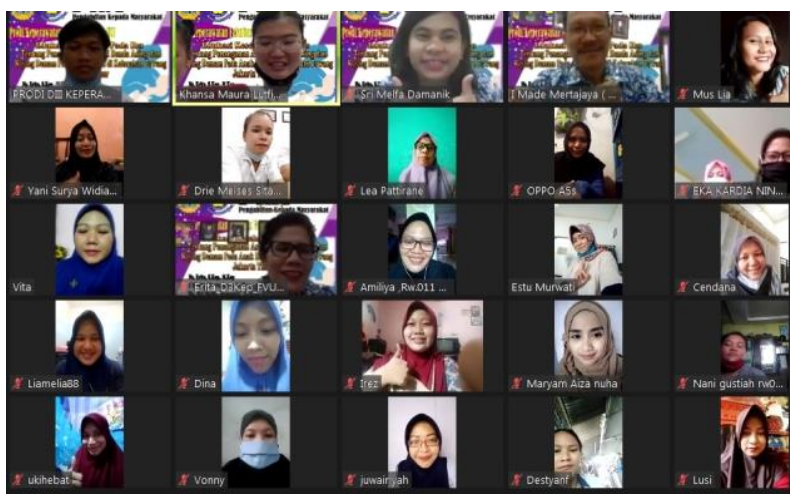

Gambar 2. Warga Cawang tampak antusias menghadiri kegiatan PkM yang dilakukan oleh Dosen dan Mahasiswa Prodi DIII Keperawatan Fakultas Vokasi UKI
Pengetahuan ibu tentang penanganan aspirasi benda asing dan kejang demam merupakan sebuah langkah awal untuk dapat mengurangi angka kejadian cedera apada anak di Indonesia. Dengan adanya sosialisasi tentang penanganan aspirasi benda asing dan kejang demam pada anak secara rutin dilakukan di masyarakat diharapkan ibu dapat memgaplikasikan ilmu yang telah diperoleh dan dapat melakukan tindakan pertolongan pertama bila menemukan anak yang mengalami kejang demam ataupun tersedak.

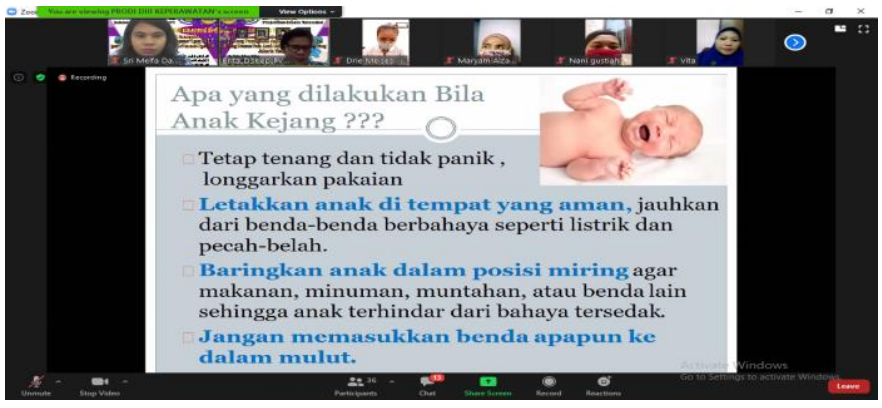

Gambar 3. Penyuluhan dilakukan secara daring melalui aplikasi Zoom

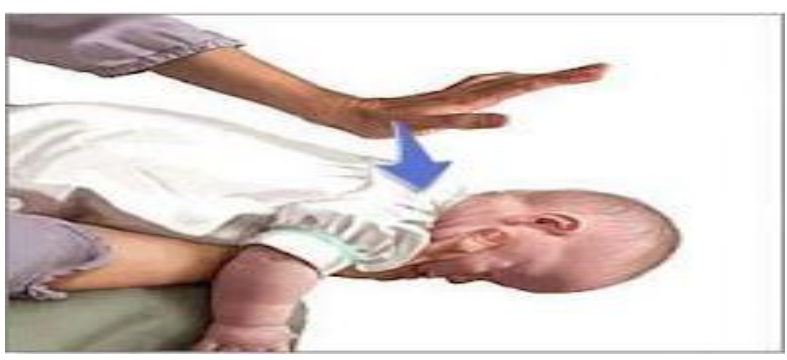

Gambar 4. Tehnik pertolongan Bayi tersedak dengan "Back Blow" 


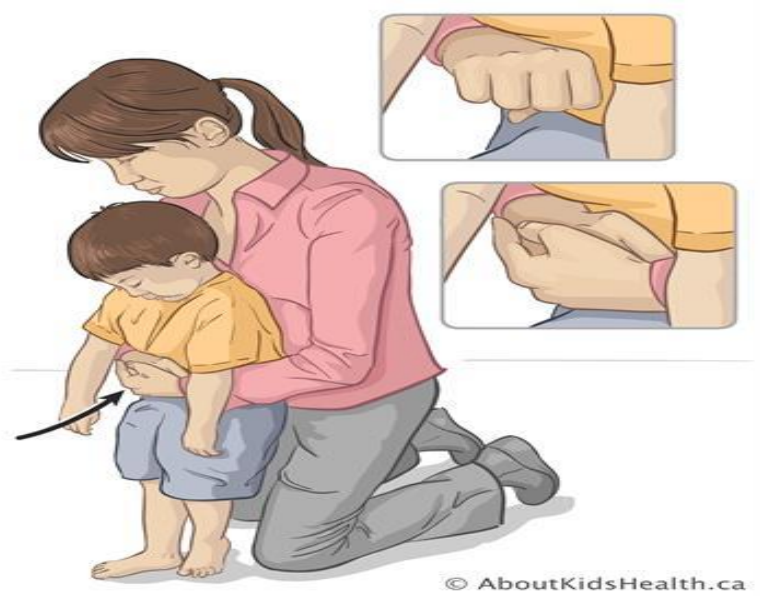

Gambar 5. Tehnik pertolongan Bayi tersedak dengan "Abdominal Thrust"

\section{SIMPULAN}

Pemberian edukasi kesehatan tentang penanganan aspirasi benda asing dan kejang demam pada anak merupakan strategi penting yang perlu dilakukan untuk meningkatkan pengetahuan masyarakat tentang dampak dan bahaya tersedak ataupun kejang pada anak. Pemberian edukasi diketahui dapat meningkatkan pengetahuan baru bagi ibu yang memiliki anak balita di kelurahan Cawang, Jakarta Timur. Pemberian edukasi yang dilakukan secara rutin di masyarakat dapat menjadi salah satu solusi yang tepat untuk meningkatkan derajat kesehatan masyarakat dan mengurangi angka kejadian mortalitas dan morbiditas pada masyarakat khsususnya pada anak di Indonesia.

\section{UCAPAN TERIMA KASIH}

Puji dan syukur penulis panjatkan kepada Tuhan Yang Maha Esa, karena berkat rahmat dan karuniaNya Kegiatan Pengabdian kepada Masyarakat Program Studi DIII Keperawatan UKI dapat berjalan dengan baik. Penulis juga mengucapkan terima kasih kepada : Pimpinan Universitas Kristen Indonesia yang telah memfasilitasi dana demi terselenggaranya kegiatan pengabdian kepada masyarakat ini, Pimpinan Lembaga penelitian dan Pengabdian Masyarakat (LPPM) Universitas Kristen Indonesia yang telah membantu dalam proses mulai dari penyusunan proposal hingga penyusunan laporan PkM, Dekan Fakultas Vokasi dan Kaprodi DIII Keperawatan UKI yang telah memberikan dukungan dalam kegiatan PkM ini serta Kepala Puskesmas Kelurahan Cawang yang sudah memberikan izin melaksanakan PkM di Kelurahan Cawang, Jakarta Timur

\section{REFERENSI}

Bowden, V.R., \& Greenberg, C.S. (2010). Children and their families: The continuum of care (2nd ed.).China: Wolter Kluwer Health.

Canadian Paediatric Society. (2012). Preventing choking and suffocation in children. Paediatrics \& Child Health, Volume 17, Issue 2, 1 February 2012, Pages 91-92,.

https://doi.org/10.1093/pch/17.2.91

Crandall, M., Sridharan, L., \& Schermer, C. (2011). Injury and health among children in vulnerable families. Journal of Trauma - Injury, Infection and Critical Care, 70(6), 1539-1545. 
Volume 3, Nomor 2, Tahun 2021 Hal 653 - 661

https://doi.org/10.1097/TA.0b013e3

$182190 \mathrm{~b} 94$

Kyle, T.,\& Carman, S. (2013). Essential of pediatric nursing (2nd ed.). Philadelphia: Wolter Kluwer Health.

Badan Penelitian dan Pengembangan Kesehatan Kemenkes RI. (2013). Riset Kesehatan Dasar: Riskesdas 2013. Diakses pada 19 April 2020, dari http://www.depkes.go.id/resources/do wnload/general/Hasil\%20Riskesdas\% 20 2013.pdf.

Potter, P.A, Perry, A.G. 2005. Buku Ajar FundamentalKeperawatan : Konsep, Proses dan Praktek, Edisi4, Volume 2, Alih Bahasa : Renata Komalasari,dkk, Jakarta : EGC.

Peraturan Mentri Kesehatan No. 19 tahun 2016 tentang Sistem Penanggulangan Gawat Darurat Terpadu, pdf.

WHO. (2016). Paediatric emergenncy triage, assessment and treatment: Care of critically ill children. Geneva: World Health Organization. 